総

説

\title{
緑内障および内眼筋の神経性液性調節
}

\author{
山口大学医学部眼科学教室 \\ 鈴木亮 \\ INTRAOCULAR SMOOTH MUSCLE PHYSIOLOGY \\ RELATING TO PATHOGENESIS AND \\ THERAPY OF GLAUCOMA \\ Ryo SuzukI MD \\ Department of Ophthalmogy, Yamaguchi University School of Medicine
}

序

内眼筋は遠近調節機能のために重要な組織で ある.また，内眼筋は緑内障の発症や治療の上 でもその観察が重要である。内眼筋は豊富な神 経支配を受けている。その伝達物質は acetylcholine (Ach) や norepinephrine (NE) ばかり でなく,ペプタイドやプリンも関与している.ま た prostaglandin（PG）やその他の autacoids が緑内障や遠近調節の生理や病態と関連してい るかもしれない.

隅角は虹彩と角膜で囲まれた部位で, 房水は この隅角の内眼筋を通りながら Schlemm 管に 流入し，上強膜静脈に至ることになる．房水の 一部は毛様体筋の細胞間隙やブドウ膜強膜経路 を通過する，房水の経路が何らかの理由で塞ぎ とめられると, 眼圧が上昇する。

緑内障は大別すると閉塞隅角緑内障と開放緑 内障がある. 周辺虹彩が角膜に接近して膨隆す るために房水が隅角組織に到達できなくなる閉 塞隅角緑内障は, レーザーで周辺虹彩に通路を 作成することにより寛解する。したがって現実 問題としては困難な臨床上の問題があるが, 閉 塞隅角緑内障でなく, 理論的には開放隅角緑内 障の発症機構を眼科医は研究し論じればよいこ とになる。

緑内障では眼圧が上昇するために視神経が萎
縮し色調が蒼白となり，いわゆる視神経乳頭の 陥凹が生じる。また視野障害が進行し，ついに は患者は視機能を失ってしまう。緑内障では角 膜, 視神経, 網膜, 視野が影響を受ける。

なぜ，眼を広汎に障害する緑内障が生じるか というと, 毛様体で産生された房水が線維柱帯 組織と静脈系の間で房水が流れさる経路が障害 されることによる．房水の流れやその流出障害 は内眼筋や内眼筋周囲の組織と関連しているは ずである。しかしながら内眼筋の収縮弛緩に関 連させて眼の平滑筋の観点から論じた緑内障や 房水流出率の総説はないようである.

本論文では内眼筋が房水流失に如何なる影響 を与えるか, また内眼筋ないしその周囲組織, 特 に線維柱帯内皮細胞の病態が “収縮”という筋 肉と共通の言葉でどのように捉えられるか, こ れらを緑内障の治療の立場と内眼筋の収縮応答 の観点から概説する。また緑内障が慢性化した ときに内眼筋の機能が影響を受けるか否かを考 えたい.

\section{房水流出路の解剖と内眼筋（図 1)}

房水流出路 ${ }^{14,40)}$ は図 1 のように瞳孔括約筋, 瞳孔散大筋および毛様体筋の近傍に位置してい る. 流出路には隅角線維柱帯があり, その流路 には内皮網と呼ばれる狭い細胞間隙と細胞外物 


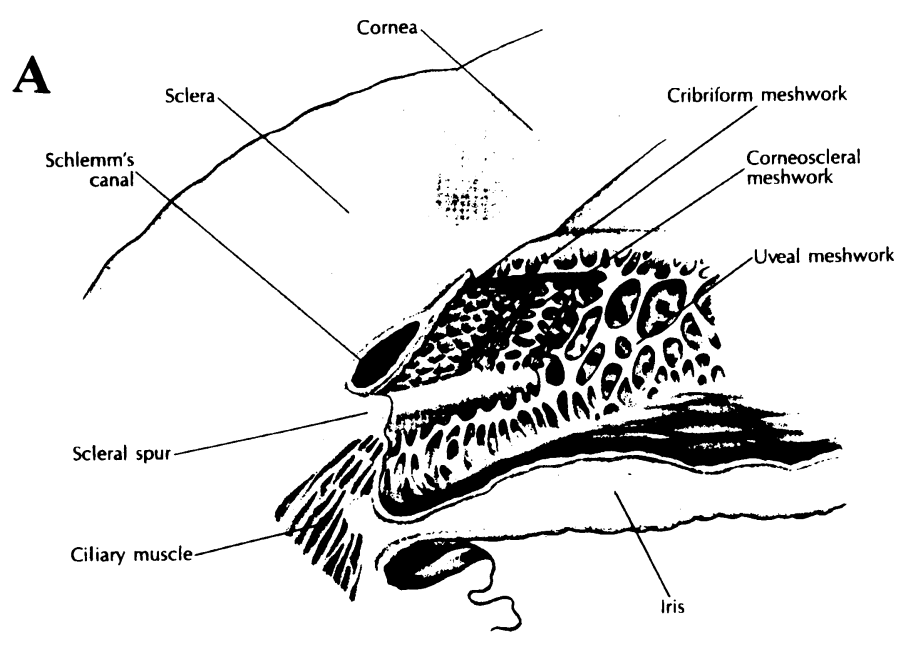

B
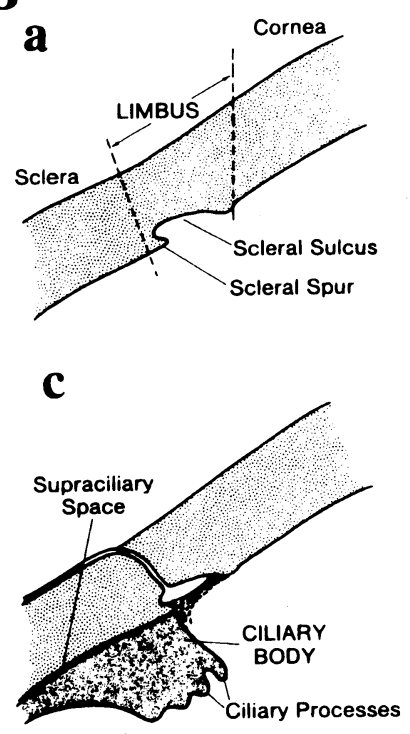
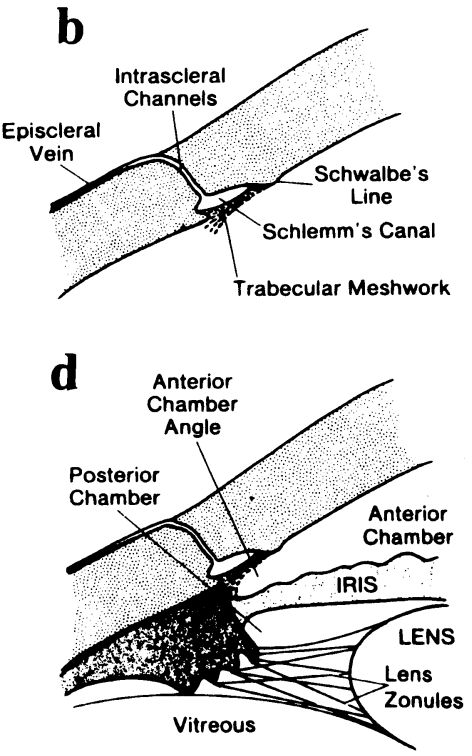

Fig. 1. Intraocular smooth muscle and glaucoma. A) Chamber angle anatomy. B) Stepwise construction of a schematic model, depicting the relationship of structures involved in aqueous humor dynamics: a, limbus; b, main route of aqueous outflow ; c, ciliary body as site of aqueous production; d, iris and lens. The figure originally presented by Shields ${ }^{40)}$ was modified.

質が存在する ${ }^{29)}$. 房水はまず，ブドウ膜内皮網， 強角膜内皮網, Schlemm 管近傍組織を通って Schlemm 管から上強膜静脈へと流出する ${ }^{19)}$. 虹 彩と毛様体筋は強膜岬の周辺に付着する. 虹彩 が隅角周囲組織のどの位置に付着するか, 毛様 体筋の牽引力が如何に隅角線維柱帯の細孔に影 響するか ${ }^{3,199}$ は緑内障の理解に必須であり, 現
在でも未知の部分であるが,ここでは述べない.

さて図 $1 \mathrm{~B}$ に示す通り, 強角膜輪部に強膜溝 とよばれる小窩が生じ血管由来の Schlemm 管 の原基が形成される。その原基と眼の前房の間 には上記の 3 層の内皮網があり, 房水はその内 皮網の間隙を通って眼外へ流出する. 前眼部の 構造は虹彩と毛様体と水晶体が別々に合体した 
と考えるとわかり易い (図 1B). 眼の中で最重 要項目の 1 つである房水流出 ${ }^{2,3,19)}$ は, 一見, 内 眼筋 ${ }^{39,44,55,61)}$ と基本的に別の問題と考えられが ちである。

\section{緑内障の種類（図 2)}

房水の流出障害を大別すると前述の通り，閉 塞隅角緑内障と開放隅角緑内障 ${ }^{14)}$ に分けられ る. 3 つの内眼筋の収縮状態や位置関係で房水 流出の質と量は大きく変ってくる.内眼筋が如 何にこの病気に大切かがわかる.

図 2 のように閉塞隅角緑内障により，房水が 隅角と接触できなくなると急性に眼圧が上昇し 瞳孔と水晶体の間吵を房水が通過することが出 来ない ${ }^{19)}$.このいわゆる瞳孔ブロック ${ }^{14)}$ が生じ ると，瞳孔散大筋を含む部分が前房側へ膨瘤し 角膜に接近ないし接触する。このような場合, 通 常, 瞳孔散大筋を含む虹彩の一部を切除し, 虹 彩を挟んだ前房と後房の水圧差をなくすと，虹 彩の膨瘤は寛解し, 虹彩根部は隅角流出路を閉 塞しないようになる。つまり，いわゆる閉塞隅 角緑内障は考慮しなくてよくなる。換言すれば 原発閉塞隅角緑内障は虹彩切除によって理論的 には開放隅角緑内障の問題になる。

ところで房水流出に神経性または hormonal な流出機構があるとは現時点では考えられてい ない.というよりは, この種の研究は形態学的 研究 ${ }^{29,57)}$ が主体であり, 生理学的研究はまだほ

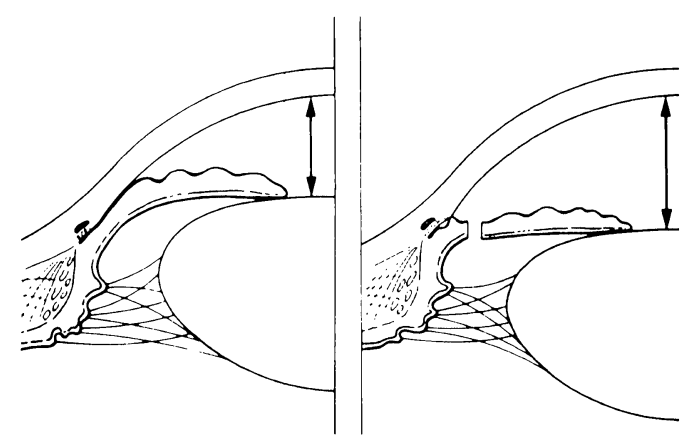

Fig. 2. Iridectomy or a hole at peripheral iris. When iridectomy is performed, the new opening allows the iris to fall away from the angle, giving free access to the trabecular area and avoiding the likelihood of synechia formation. This surgery works to form a peripheral by-pass.

とんどなされていないのである。

緑内障の非観血的治療には 1 副交感神経作 働薬，2 エピネフリン， $\beta$ ブロッカー等の交感 神経系薬物 ${ }^{17,53)}$ 抢よび 3 レーザー隅角形成術 (LTP) ${ }^{50)}$ がある.

どの治療方法にも未解決の問題点があり, 緑 内障は現在でも失明に到る重篤な眼疾患であ る.順を追って治療法の問題点を内眼筋との関 連から考えたい。まず副交感神経作働薬につい て述べる。

\section{緑内障の治療 -1 副交感神経関連薬の問題点}

\section{虹彩の神経支配}

虹彩には副交感神経と交感神経があり, 主と して瞳孔括約筋と瞳孔散大筋に分布している。 散大筋は瞳孔を開かせる筋肉で, 眼圧, 眼底検 查や閉塞隅角緑内障の発症に関与している. 従 来は瞳孔括約筋は副交感神経支配（動眼神経経 由）で縮瞳し, 瞳孔散大筋は交感神経支配で散 瞳すると考えられていた。

瞳孔括約筋と瞳孔散大筋は接近して存在して いるから，筋の受容体は似たような性質をもっ ていると予想していた。ところが, ウシでは瞳
孔散大筋においても神経刺激により副交感神経 性の弛緩反応を記録45)することができた。

交感神経系の反応も propranolol では阻害で きなかったものの, $\beta$ 括抗薬である timoptol や sotalol で阻害された。この反応がなぜ propranolol で抑制されないかは現在も不明であ る。いわゆる $\beta_{1}, \beta_{2}$ 以外の $\beta$ 受容体を介してい る可能性がある.ラット ${ }^{33,41)}$ は特異的で，その 後, イヌ ${ }^{64)}$, ヒトなどでも同様の反応が見い出さ れている。

瞳孔散大筋は平滑筋であるのに agonist であ 
るはずの Ach で弛緩するのである.瞳孔散大筋 は虹彩の色素上皮が変化したもので外胚薬性で あり，通常の筋肉とは異なる。またこの弛緩反 応は最近のトピックである NO などを介した ものではなく筋の受容体に Ach が作用した結 果である。いずれにせよ副交感神経の興奮によ り瞳孔散大筋が弛緩すると，そのとき瞳孔括約 筋は収縮するので，両筋があいまって協調性に もしくは相加的に縮瞳をひきおこすことにな る.興味あることは, 瞳孔括約筋の収縮の方が 瞳孔散大筋の弛緩より常に速い48)ことである. 瞳孔散大筋は，何故か必ず遅れながら瞳孔括約 筋の反応を助けるように作用する。つまり副交 感神経作働薬は瞳孔散大筋にも作用して縮瞳を 助けてくれ, 更に眼圧低下の役にも立つ.

ところがラットではAch の濃度により低濃 度では弛緩し高濃度では収縮に転じるという。 この珍しい現象はWatanabe等そしてTakayanagi 等により発見されていた ${ }^{30,33,41)}$ が, 臨 床的意義は見当がつかない.下等動物ほど虹彩 の筋細胞が光に対して反応するので, 弱い光に 対する生物的対応が瞳孔散大筋自身にあるのか もしれない.ラットやハムスターの眼圧は比較 的高い (未発表) のであるが, 緑内障とはいえ ない. 緑内障を自然発症する動物は少なく, サ ルで持続的な高眼圧を作るには大きな出力の
レーザー照射をおこなう必要がある。緑内障は 一般的にはヒトに特有の疾病なのである.

内眼筋における豊富なコリンエステラーゼ

(chE)

内眼筋は濃密な神経支配を受けている. カル バコール (Cch) は chEで分解されないだけ, Ach より強力である.ところが, 瞳孔括約筋の Cch と Ach の濃度-作用曲線をみると, 収縮効 果が非常に異なる49)ことがわかった.ウシ内眼 筋では Cch はAchより数千倍近い効果があ る.それだけAch を瞬時にして分解してしまう 程, chE が内眼筋に豊富である。これほど差の ある組織は哺乳動物の自律神経組織にはみられ ない. 電気ウナギでさえも Cch と Ach の価の 差は約 1,000 倍 ${ }^{38)}$ にすぎない.このようなこと から, 緊急時に強力に患者さんを縮瞳させる必 要のあるときは我々は pilocarpine だけでなく chE 阻害剤である eserineを使用している。但 し, ラットやウサギではこれだけ強力な違いは Ach と Cch の間にないようである ${ }^{33,39,40)}$.

\section{毛様体筋の収縮応答（図 3)}

毛様体筋を電気で神経刺激をすると, 種々の 資源頻度で美しい収縮活動 ${ }^{44)}$ を示した。毛様体 筋の収縮は隅角線維柱帯組織を牽引するので房 水の排出を促進する ${ }^{4,15,16)}$, 毛椂体筋を収縮させ る Ach, ピロカルビン, Cch を点眼すると眼圧
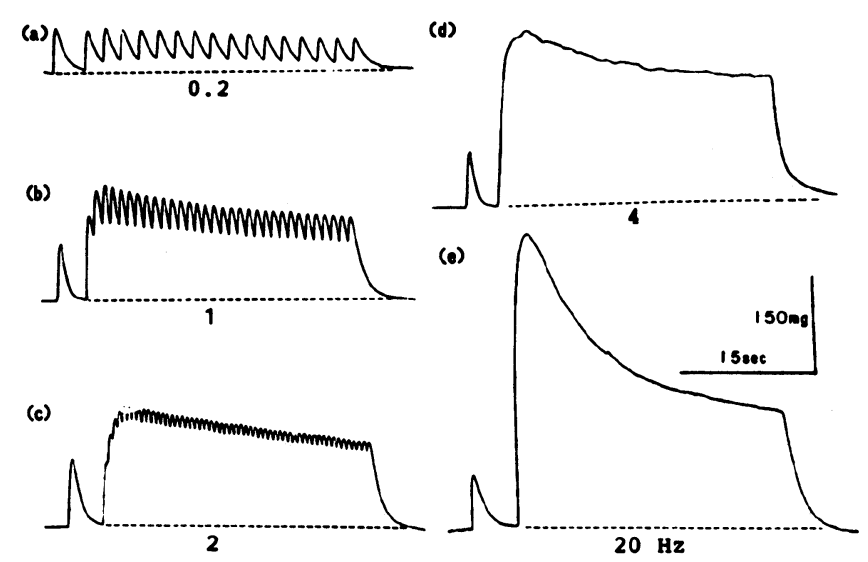

Fig. 3. Effects of increasing the frequency of train pulses with constant duration at $0.5 \mathrm{msec}$ on the contractile response of bovine ciliary muscle. Stimulus frequency was $0.2,1.0,2.0,4.0$, and $20 \mathrm{~Hz}$ respectively, for the records $\mathrm{a}, \mathrm{b}, \mathrm{c}, \mathrm{d}$ and e. The initial contraction in each record shows a "twitch" due to a single stimulus. Originally presented by Suzuki et al. ${ }^{44)}$. 
が下がる ${ }^{23)}$.また近方調節をさせ続けておくと 眼圧が下がるといわれている。

遠近調節機能の全くない患者や老人にピロカ ルピンを点眼しても, 眼圧が下がるので, ピロ カルピンの効果が毛様体筋の収縮を介したもの かどうかはまだ不明である。ピロカルピンや Cch で毛様体筋はすぐに収縮する。しかし眼圧 の低下は時間経過として 1,000 倍以上の時間 差 ${ }^{48)}$ があり，この分野も未解明である.

動作を観察してもウシが俊敏な遠近調節反応 をおこなっているとは考光難い.しかし，ウシ 毛様体筋は twitch をはじめ, 不完全強縮の収縮 応答を示す ${ }^{44)}$. この応答のクロナキシーは子宮 筋や腸管などの内蔵平滑筋とは根本的に異なっ ている. 毛様体筋の収縮応答は骨格筋とはもち ろん全く異なる。鳥類が高空から地上の小さな 獲物を捕獲するために, 鳥類の内眼筋は焦点深 部を深くするピンポイントの機能を併せもつは ずである，多くの想像は可能であるが，筆者の 調べた限り, 実験事実の提出は皆無である. 骨 格筋と平滑筋の機能を併せもつ内眼筋が鳥類に 発見されるかもしれない.内眼筋は実験するま で何が扢こるかわからない未知の分野の一つで ある。

\section{毛様体筋の K 拘縮（図 4）}

平滑筋は外液の $\mathrm{Na}$ を $\mathrm{K}$ に置換すると, いわ

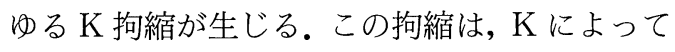
膜が脱分極し，それに伴って収縮が生じる。脱 分極による収縮は, 筋生理の基本である.とこ ろが，ウシ毛様体筋ではこのような $\mathrm{K}$ 拘縮は, アトロピンでムスカリン受容体を遮断すると, ほとんど発生しない4) ことがわかった。しかも この K 拘縮は eserineや neostigmineにより 増大寸る.このことからウシ毛様体筋は脱分極 では収縮しない, 毛様体筋を収縮させるには神 経ないし薬物を介さない限り, 収縮しえないと 結論された。

筋生理では，この現象はあり得ないことだと 思われたが, 現在では, receptor-operated channel 膜電位非依存チャンネル (ROC) の存在 がわかっており, ウシ毛様体筋は, まさにその 典型例であった。これは従来の pharmacomechanical coupling に含めて考えることもで きるが, 動きの少ない血管平滑筋と微細で俊敏 な毛様体筋が, 少なくともみかけ上は一本の線 で連ながっていることになる。しかしながら， $\mathrm{Ca}$ の移動やその利用方法は随分異なっている と予想され, 今後の課題である. 同じ内眼筋で も虹彩の平滑筋では, アトロピン存在下に $\mathrm{K}$ 拘
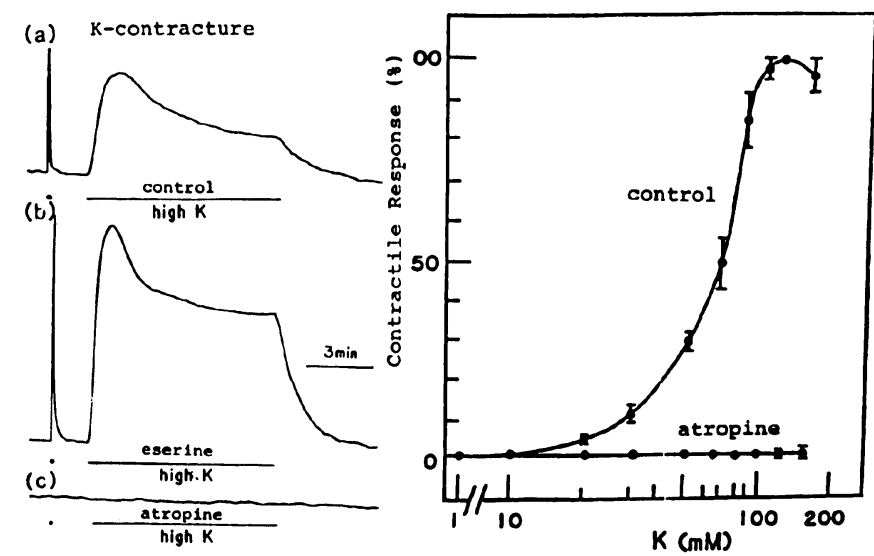

Fig. 4. K contracture of bovine ciliary muscle. K contracture of the bovine ciliary muscle was almost completely inhibited by the application of atropine and was remarkably enhanced by physostigmine or neostigmine. This suggests the presence of receptor operated channel, and depolarization perse does not cause contraction of the bovine ciliary muscle. It was later reported that the canine ciliary muscle showed a slight $\mathrm{K}$ contracture in the presence of atropine. Originally presented by Suzuki et al ${ }^{44)}$. 
縮は僅かながら存在する ${ }^{65)}$.

内眼筋における生理活性物質の役割

副交感神経系に関してこの組織における生理 活性物質の役割りを簡単に述べる。VIP は眼の

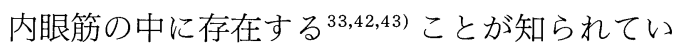
た、VIP の作用をみると，神経刺激による収縮 が，VIP 存在下で増大することがわかった。外 来性に投与したAch に対してはVIP は作用を もたないので, VIP は神経の末端に作用して

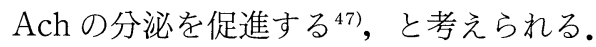

VIP は，平滑筋を弛緩させると考えていた
が, 唾液腺と同じようにVIP が眼では毛様体筋 の収縮を調節している.さらにこの VIP はブド ウ膜流出路に作用して房水の後方移動を促進す る可能性がある。

VIP は 1 例である. 眼では多くの物質 ${ }^{11,22)}$ 内眼筋の収縮を調節している可能性がある。こ れらの物質は難治性緑内障の発症 ${ }^{54}$ 亿関係し ているかもしれず，その拮抗物質 ${ }^{22)}$ が治療に応 用できるかもしれない去).

毛様体筋を介した房水流出量の増減（図 5)

毛様体筋が収縮すると強膜岬を牽引して隅角
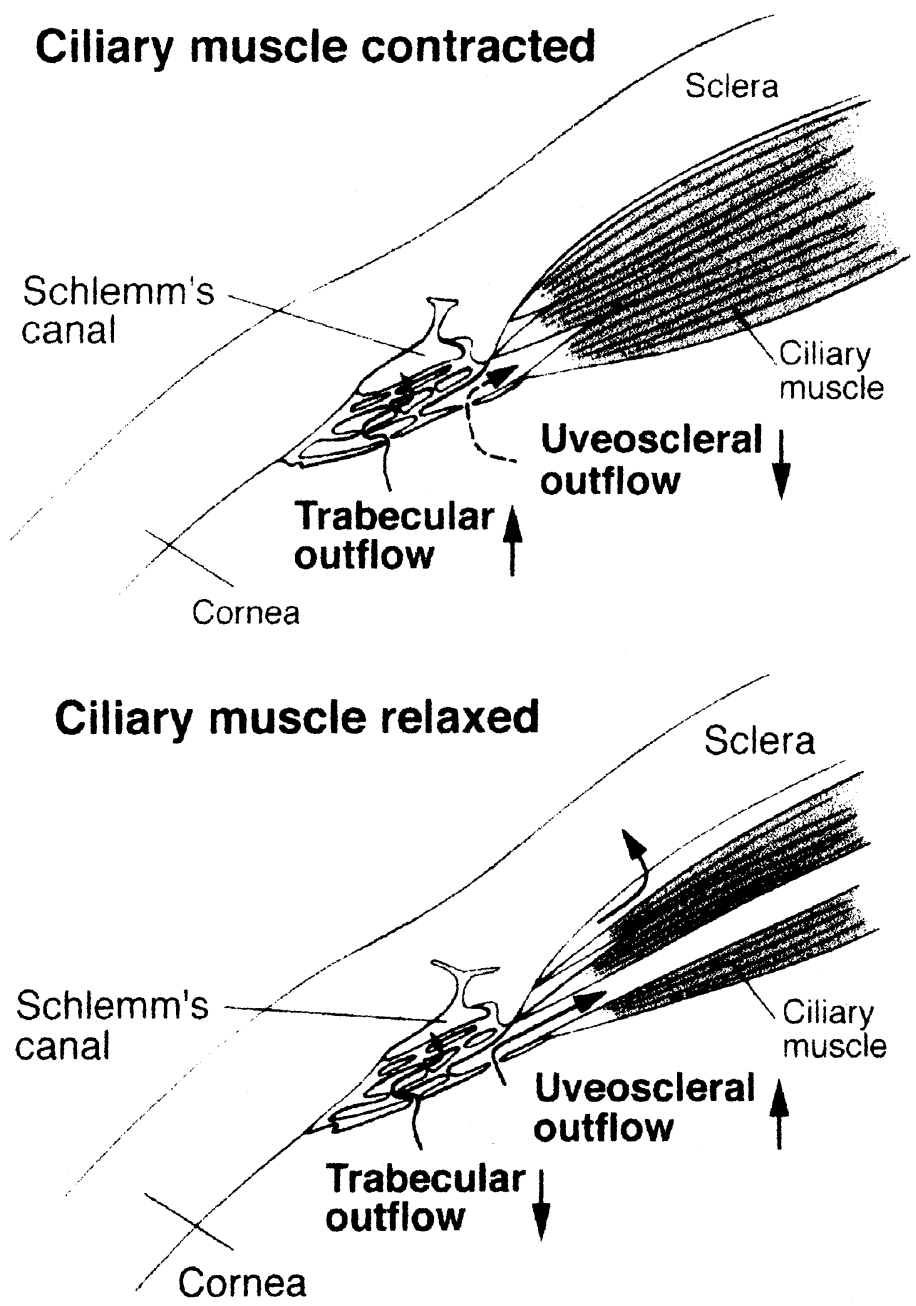

Fig. 5. Contraction and relaxation of ciliary muscle. The contraction decreases uveoscleral outflow and increases trabecular outflow, whereas the relaxation increases uveoscleral outflow and decreases trabecular outflow (Modified by Suzuki and originally proposed by Bill ${ }^{6)}$ and $\mathrm{Nilsson}^{39)}$. 
内皮網の間隙が拡大するが，毛様体筋細胞の間 吵は逆に非常に狭小化するので強膜ブドウ膜流 出量は減少する ${ }^{4}$ 。一方, 毛様体筋が弛緩すると 筋細胞間の間隙が拡大寸るので房水は図 5 の矢 印のごとくブドウ膜経路を通って流出す る ${ }^{12,18)}$. いずれの場合も房水の流出量は経隅角 流出量と経強膜ブドウ膜流出量の和である。七 卜に扔いては隅角経由の房水流出量の方が圧倒 的に大きいとされているが，本年から市販され はじめた $\mathrm{PG}$ 誘導体の点眼薬9) はブドウ膜強膜 流量を増量させると考えられている。興味ある ことに, 緑内障は加齢とともに発症率が増すが， 摘出内眼筋の張力は年齢であまり差がない ${ }^{56)}$.

PGs ほど眼科で悪者扱いされていた物質は 珍しい. PG は以前は irin とよばれ, 眼の起突物 質と考えられていた。眼の炎症は縮瞳，眼圧の 上昇, 眼内のタンパク濃度の上昇と, 結膜の充 血をひきおこす。PGsをウシ眼に投与すると， 必ずしも縮瞳しなかった ${ }^{46)} し$ ，瞳孔括約筋の トーヌス ${ }^{7,61)}$ により，PGs はむしろ瞳孔括約筋 を弛緩させ，散曈の方向に作用することがわ
かった。Camras は PGsが眼圧を下げることを 見い出した。 $\mathrm{PG}$ 誘導体の点眼薬 ${ }^{34)}$ も使われる ようになるほど，時代は大きく変化したのだと 痛感する。

超音波生体顕微鏡 (UBM) による画像観察 (図 6)

図 9 に超音波生体顕微鏡 (UBM) による房水 の移動を示す. UBM により,薬物によって房水 が隅角ばかりでなく，毛様体筋の間隙を通って 流出することがわかった。通常では強膜と毛様 体の間隙や毛様体（ブドウ膜）の細胞間隙に房 水は流れない(図 6a) が, indomethacin で処理 した後に prostaglandin $\mathrm{F}_{2 \mathrm{a}}$ を潅流するとその 間隙に房水が流れ，いわゆる液面が形成され る ${ }^{54)}$ (図 6b)。また縮瞳, 散瞳に対し虹彩は単に 収縮したり弛緩反応するだけではない。たとえ ば散瞳に対しては虹彩の幅は前後径が著明に厚 くなるし，縮瞳に対しては周辺虹彩と隅角が変 化することがわかった。UBM では内眼筋の動 きが画像として動的に観察できる.内眼筋は単 に光量の調節や遠近調節に関与しているだけで はなさそうである。
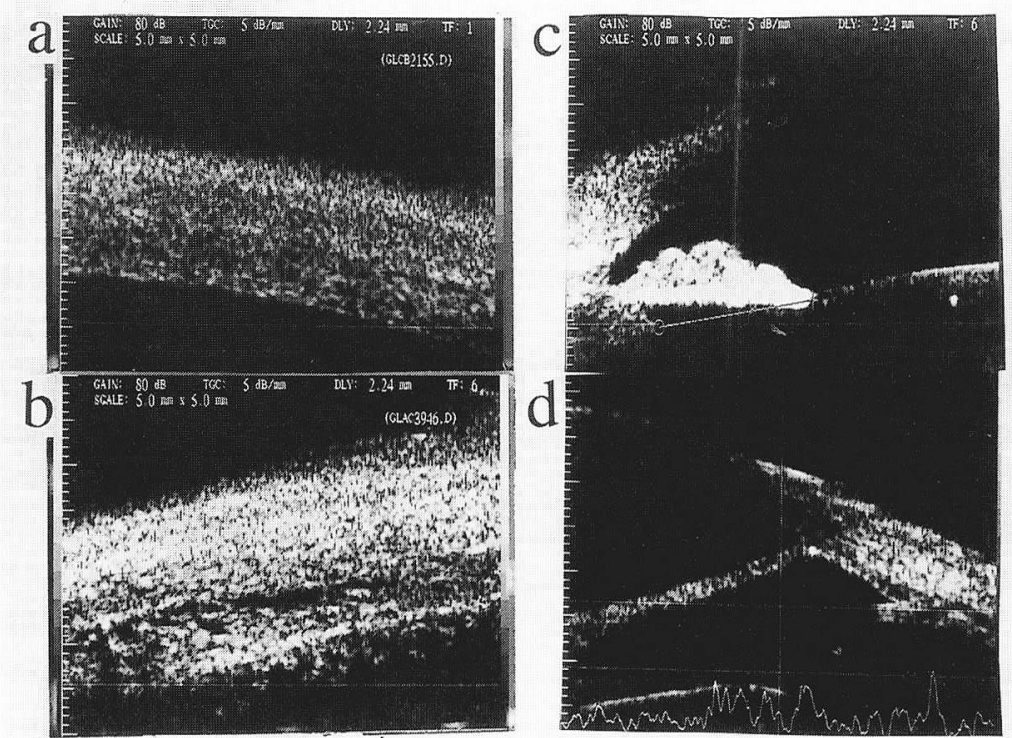

Fig. 6. Observation by ultrabiomicroscopy. In the presence of indomethacin and prostaglandin $\mathrm{F}_{2 \mathrm{a}}$, uveoscleral fluid (b) is observed. Mydriasis (c) or miosis (d) does not only mean relaxation or contraction of the iris, but also show the change of the angle perse, peripheral and middle part of the iris and the ciliary muscle location. Originally presented by Suzuki. 
Table 1. Difference in the degree to which the IOP is calculated to be affected by changes in flow (F) and facility of outflow (C) in different types of eyes.

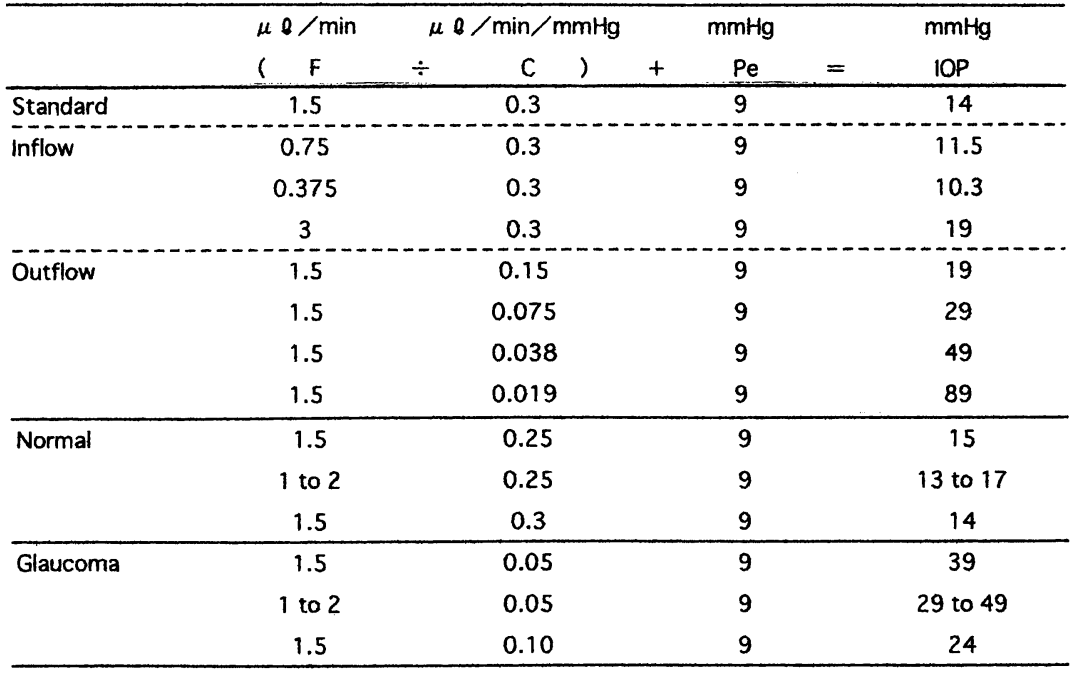

\section{眼圧を規定する房水の流出率の重要性（表 1)}

表 1 に示すとおり,眼圧は房水産生量 $(\mu 1 /$ 分/ $\mathrm{mmHg}$ )を時間（min）と灌流圧 $(\mathrm{mmHg})$ の 積で除した值に上強膜静脈圧を加えて得られ る ${ }^{14)}$. 標準では房水産生量は $1.5 \mu \mathrm{l} /$ 分 $/ \mathrm{mmHg}$ でC 值は 0.3 なので眼圧は $14 \mathrm{mmHg}$ 相当で ある(表 1).

最大限に房水産生を減らし，そして半分に房 水産生がなったとしても，眼圧は $11.5 \mathrm{mmHg}$ (表 1) であるので，変化量はわずか $2.5 \mathrm{mmHg}$ である。どんな薬物を大量に与えても不可能な ことだが，たとえ房水産生利用を $1 / 4$ に減少さ せえたとしても眼圧は $10.3 \mathrm{mmHg}$ (表 1) でわ ずか $3.7 \mathrm{mmHg}$ の減少にすぎない. その反対 に, 房水流出率が $0.2 \sim 0.3$ と一定である限り, 房水産生量が 2 倍に増えても眼圧は $19 \mathrm{mg}$ な ので眼圧は思いの外, $20 \mathrm{mmHg}$ 程度以上には 変化しない。しかしながら緑内障では 20 $\mathrm{mmHg}$ 以上の眼圧上昇が多く見られる。それは なぜか.

流出率 $\mathrm{C}$ 値が下がると，眼圧は上昇する．臨 床的にこのC值は患者さんによっては限りな く0に近づくので, 眼圧は眼球が圧に耐えられ なくなるまで $29,49,89 \cdots \cdots$.少非常に上昇する.
さらに表 1 から明らかなように，正常眼では 房水産生が $33 \%$ 変化しても, つまり房水産生量 が 1 ないし $2 \mathrm{ml} /$ 分となっても, 眼圧はわずか 2 $\mathrm{mmHg}$ 変化する (15 から 13 または 17) だけで あり，C值が 0.5 増加しても眼圧は 15 から 14 へ $1 \mathrm{mmHg}$ 下がる程度（表 1) である。しかし ながら緑内障眼では房水産生の同じだけの変 化，たとえば $33 \%$ の変化に対し，眼圧は 15 か らそれぞれ 29, 49 (表 1) へ, $14 \mathrm{mmHg}$ ないし $34 \mathrm{mmHg}$ も大きく変化する。また C 值が 0.05 増加するだけで眼圧を $15 \mathrm{mmHg}$ も下げること が出来る (表 1)。すなわち眼圧は流出率を上げ ることによってのみ最も効果的に下る. 眼圧に 対しては房水流出率が大切 ${ }^{19)}$ なゆえんである.

眼球は $20 \mathrm{~mm}$ たらずの小さな器官である. この眼球に形を与えているのは，いわゆる眼圧 である。緑内障のみならず，ブドウ膜炎，白内 障, 網膜剥離, 糖尿病網膜症, 眼内手術などに おいて眼科医にとっては眼圧はとても大切であ るにもかかわらず，この房水流出の研究が依然 として発展しないのは房水流出率の実測が困難 なことやその改善薬が見い出されていないから ではないか，と筆者は考える。 

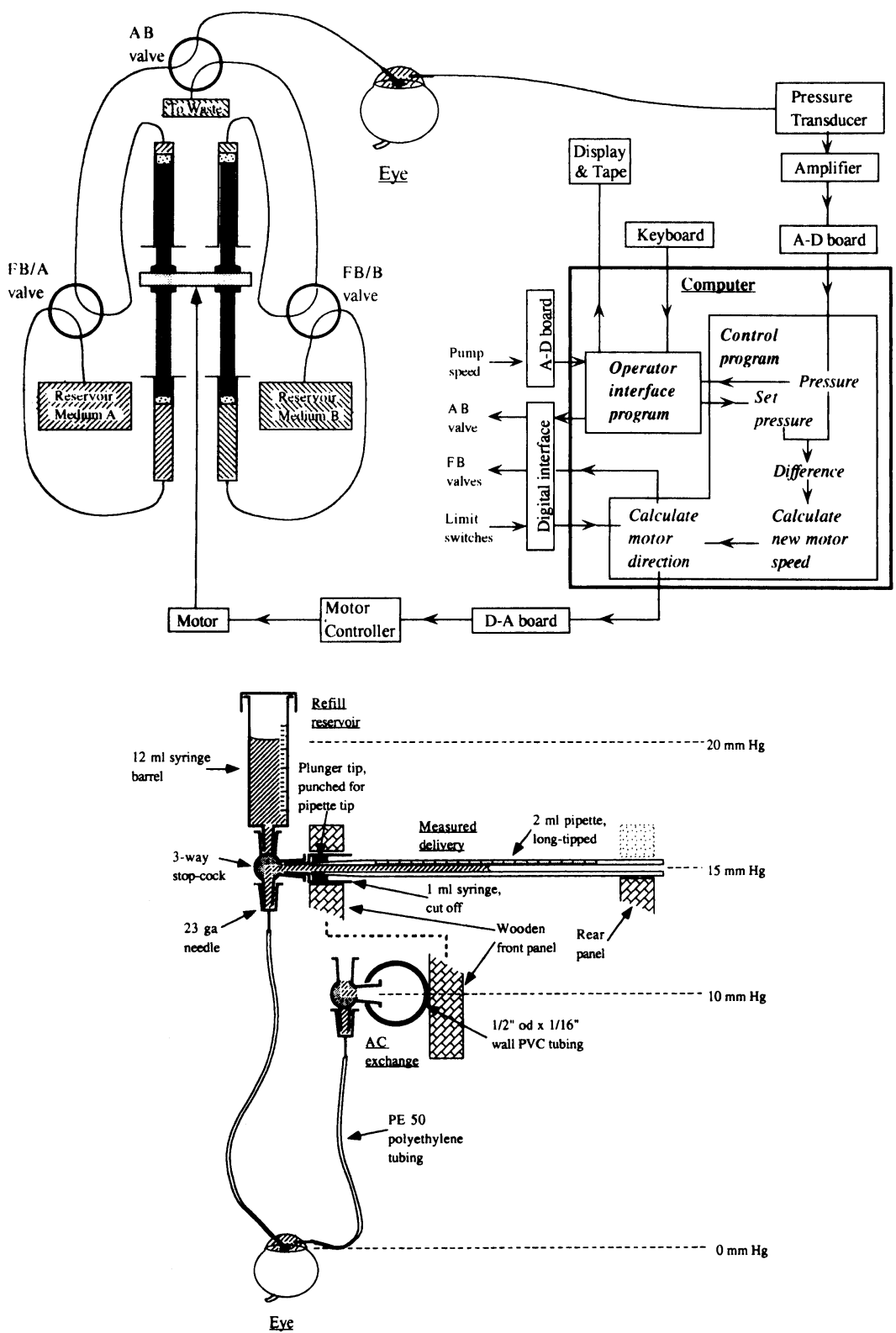

Fig. 7. Ocular perfusion method. The eye can be perfused with various pressures. Upper, an advanced method; lower, a simple method. Originally presented by Suzuki ${ }^{53)}$.

\section{房水流出量測定の実験系（図 7)}

図 7 は房水流出量を測定するための我々の 2 つの実験系 ${ }^{52)}$ である.コンピューター制御の方 法で我々は今では眼内に流入する薬液とその注 入圧を制御することが出来る。その一方，スク リーニング系としては一定の高さから眼内に
BSS を注入すると, 定常状態では流入量は流出 量に等しいことを利用して房水流出率は, 前述 のごとく流入量とその高さ $(\mathrm{mmHg})$ およびそ れに要した時間で決定することも出来る ${ }^{5,18,52)}$.

家兔においては，SP が著明な縮瞳をひきお こす4)ことが古くから知られていた。 その後, 
Ueda らの摘出家鬼虹彩筋の実験 ${ }^{59,60)}$ から，家 鬼ではSP が瞳孔括約筋の伝達物質であるらし いことがわかった。ヒトではSP は重要ではな さそうであるが，しかし特に内眼筋は神経支配 が密なので豊富な mediator ${ }^{22)}$ があり，それが 何らかの役割をもっているであろう。それを調 べていくと筋の位置関係や収縮状態と緑内障の 関係を知ることが出来るかもしれない。
眼圧や内眼筋の運動を変化させる因子には上 記のPG に加え, CGRP, SP, VIP, ATP P $20,22,43)^{2}$ などがある。これらは内眼筋の運動を調節する ばかりでなく，眼圧にも影響する。ある種の緑 内障はそれらの物質によって眼圧上昇が生じて いるのではないか，その場合，必ずしも房水流 出路の物理的閉塞がなくても眼圧が上昇する可 能性があると考える。

\section{緑内障の治療-2 交感神経系の薬物をめぐる問題点}

緑内障の治療薬としてエピネフリンと $\beta$ ブ ロッカーが汎用されている。しかしその内眼筋 への作用は種差 ${ }^{311}$ が複雑でここには記さない.

平滑筋の性質に種差や部位差があることは常 識であるが，内眼筋の種差はとても大きい。

点眼薬による隅角細胞の形態変化（図 8)

薬物の効果は個人差がある.たとえば年齢, 屈 折異常, 視神経障害, 毛様体筋の調節能力が同 じであっても， $\beta$ ブロッカーやピロカルピンの 効果は患者さんによって相当異なる。午の理由 を我々は次の上うに考えている。
同じ点眼薬を与えても，そのときの患者さん の隅角の病状ないし傷害状況によって細胞は器 質的，機能的な変化を受け，たとえば浮腫状に なる。そうすると，同じ刺激であっても，細胞 が弱っていたり濃度が違うと, 細胞は例えば ruptureしてその ruptureのために流出路が blockされてしまうかもしれない。即ち甲には 薬であっても乙には毒であるかもしれない。前 述した通り隅角には 3 層あるので，刺激に強い 細胞群もあれば刺激に敏感な細胞群があっても よいと思う。またこれらは別のオリジンの細胞
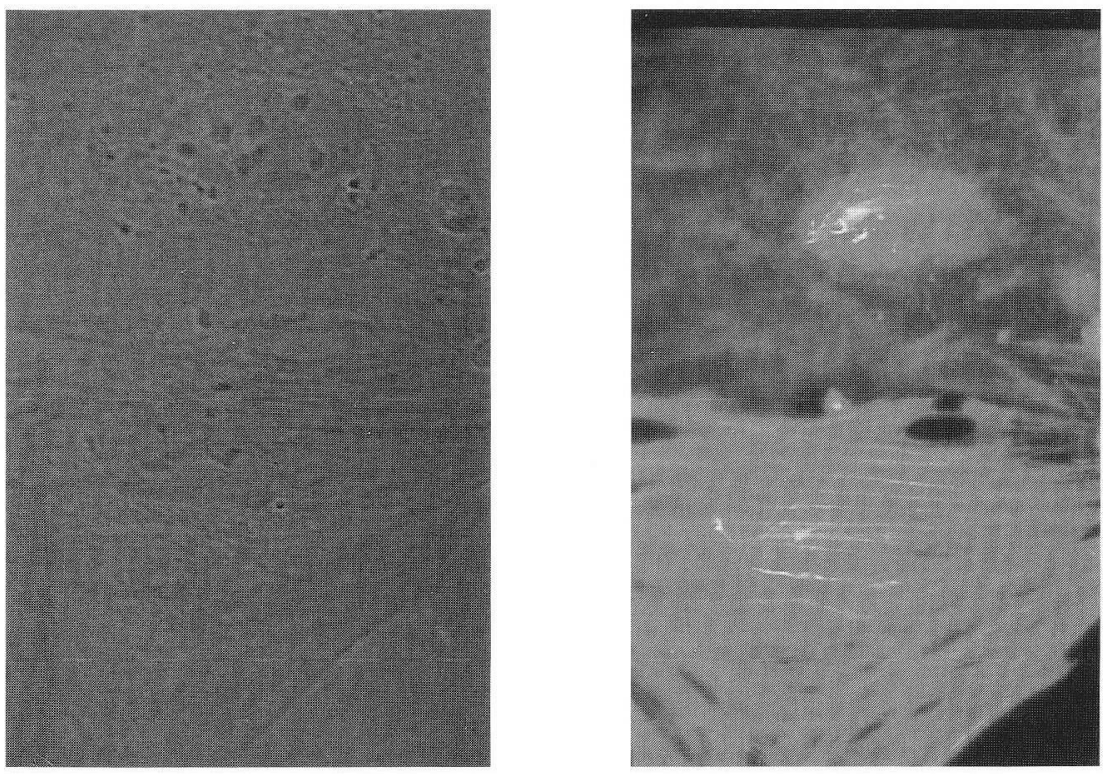

Fig. 8. Cultured trabecular cells. There are at least two types of cultured trabecular cells. Some cells tend to react to a certain drug, while other cells have no such a tendency. Two types are also evident from the difference of staining characteristiscs. Left, phase-contrast microscopy ; right, actin staining. Originally presented by Suzuki. 
であるかもしれない（図 8).

このような考えから流出率を上げるために流 出路の細胞を培養した，房水はごく狭い細胞間

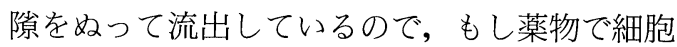
形態を少しでもかえることが出来たら，房水流 出率は著明に上昇するはずである。ただしどん なに丁寧に隅角組織から細胞を採っても，少な くとも2 種類の細胞が培養されている ${ }^{8,27,53)}$ とがわかる．薬物に対する細胞の応答性とモノ クロナル抗体の染色態度の差からもそれが明ら かである(図 8).

培養隅角内皮細胞8,10)をみると, 点眼液で 我々が使っているエピネコリンでアクチンが収 縮していることがわかった.ごく低濃度から，あ たかも筋肉のように，あるいはそれ以上に隅角 の細胞は変化する。

点眼を続けている緑内障患者では眼圧降下度 が減退し薬物の感受性が低下することが知られ ている。これは点眼により細胞機能が変化し初 期には房水流出率が改善するが, 漸時, 細胞外 物質へ影響したり内皮細胞自体の機能不全が生 じてしまうため眼圧降下が劣化するのであろ う.内皮細胞が変性したり細胞が脱落すること
によりコラーゲンが房水に直接暴露されること が緑内障の本質 ${ }^{53,54)}$ かもしれない.

隅角細胞の形態变化と房水流出率 (図 9)

ところで epinephrine は房水流出を増加さ せ，隅角内皮細胞には組織化学的に $\beta 2$ 受容体 が存在する ${ }^{30,36)}$ とされている。が，実際の灌流 実験で epinephrine が房水流出率を上げたとい う摘出眼の実験結果はない.このため epinephrine の眼圧下降は動物で 3 期に分類され, 房 水産生と排出のバランスの問題として扱われて いる ${ }^{14,40)}$ が，実際の眼圧下降機構は未だ不明で ある。

実際, epinephrine, norepinephrin (NE), dobutamine ( $\beta 1$ agonist), salbutamol ( $\beta 2$ agonist）は流出率を上昇させることはなかっ た ${ }^{53)}$. 図 9 に示すと抢り房水流出率に及湾す薬 物の効果を, 対照眼と比較すると epinephrine, isoproterenol および dobutamine は高濃度で も房水流出率を上げず，むしろ経時するにつれ 薬物を灌流した側の房水流出率の方が低下し た。しかしながら PDE 抑制剤は極めて強力に 流出率を上昇させた。

培養隅角内皮細胞を用いて同じことを検討す

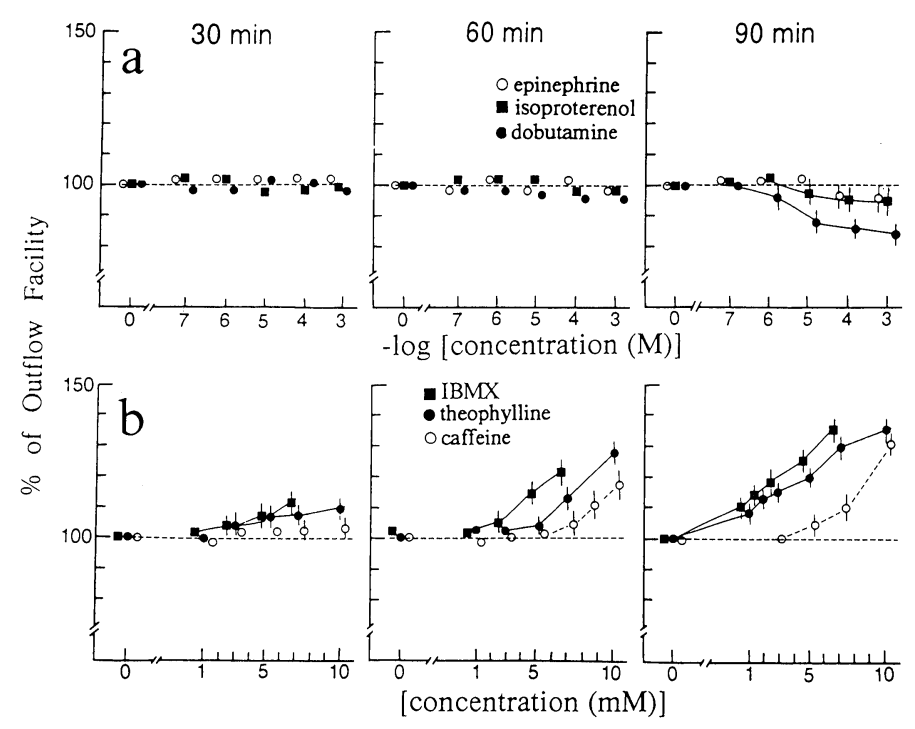

Fig. 9. Effects of adrenergic $\beta$ agonists and PDE inhibitors on outflow facility of enucleated calf eyes tested at $36^{\circ} \mathrm{C}$. PDE, phosphodiesterase; IBMX, isobutyl-methylxanthine. $n=4-5$. mean \pm SE. Originally presented by Suzuki ${ }^{53)}$. 
ると, 低濃度の theophylline が存在すると交感 神経作働薬の効果は急に著しくなり, 早期に出 現する。 $\beta$ 作働薬と PDE 阻害薬の間には相乗 作用が明らかであり, cAMP, dB-cAMPゃ adenosine も類似の変化を示す.この実験から, 種々の交感神経作働薬は高濃度で隅角細胞の形 態を変化させるが, 房水流出率は少なくとも 我々の観察時間内では増加しない。しかしなが ら PDE 阻害薬では細胞の形態のみならず流出 率が著明に増加する。隅角および毛様体筋など 眼圧と関係する組織において, 不思議なことに $\beta$ 作働薬よりも PDE 阻害薬の方がはるかに強 力な作用を有する.

この我々の培養細胞が生体の細胞と同じ役割 を果たしているか，また均一の細胞のみを観察 できているかどうかは不明である。しかし培養 細胞は glycosamioglycan 合成, ステロイド反 応や貪食能を有しているという報告 $8,26,58) も あ ~$ り, 生体流出路組織の機能を反映していると期 待したい.

$\beta$ 作働薬による房水流出率の変化は摘出眼で は Esickson-Lamy ${ }^{17)}$ の報告があるにすぎず, $\beta$ 作働薬が動物の摘出眼の房水流出を上昇させる という報告はまだないようである。また毛様体 筋では種差が著しいものの $\beta$ 作用による筋の 弛緩反応は小さいかもしくは無視できる ${ }^{44)}$ の に, しかしながら PDE 阻害薬は毛様体筋を強 力に弛緩反応させる ${ }^{54)}$.

以上のことから, 房水流出路近傍の細胞（隅 角内皮細胞，毛様体筋）は動物の種差に応じて それぞれ特有の $\beta$ 受容体を有し種差があるけ れぞも，その細胞の機能は豊富な PDEによっ て著しく効果の発現が抑制されている状態にあ ることが示唆される.PDE 抑制剤による著明な 効果は CAMP を介した反応であろうが,これほ ど交感神経作働薬と PDE 抑制剤の反応が異な る組織は文献上みあたらない。

ある種の PDE 抑制薬では cAMP のみでな
く cGMP が増加する.我々は現在 Zaprinast の 眼科応用を考えている。どのような機構がこの 組織の生理機能に貢献しているかわからないの で, 1 つ 1 つ確認する必要がある. Actin は phosphorylation ないし cross linking などを うける. 来年度から点眼薬が市販されることに なったが，腎臓内科で使用されるDiamox （Dx）は, 眼圧を下げるが, 房水流出率には全く 関与しない。

\section{房水流出率における組織の代謝}

仮に房水を眼外へ汲み出す生理機能があるな らば，流出量はいわゆる毒物で減少するはずで ある。我々は何種類かの薬物を試み, $\mathrm{NaF}$ で流 出量が減少する52)ことをはじめて確認した.

薬物を注入せず，低温から体温にすると流出 量は回復する.よってこの流出率の変化は, 液 の粘性変化だけでは説明できず，流出路組織に 何らかの代謝があることを示している。この結 果は, 房水流出率に細胞のエネルギーが関係し ない, という従来の定説と明らかに異なる。 そ の原因の一つは, 以前は温度に注意を払わない で，室温で眼を灌流していたからである．また 高い圧で灌流するのならば，眼の体積が増えな いように，注意すべきであったと思う．体積が 変化しないように, 温度に注意して, 我々が細 心の実験をすると房水流出率が下がる，すなわ ち汲み出し機構が制御されることがわかった。 これは Ca-free 液でもみられるので, 化学反応 による沈殿のための影響ではない ${ }^{52)}$.

隅角の細胞群はほぼ全ての動物で眼の房水の 流れを塞ぎとめるように配列している．摘出眼 でも生きた動物眼でも, 房水の流出は細胞活性 の影響を受けない ${ }^{19)}$, と結論されているが, も し, 前述のごとく, 房水の吸収に代謝が関係し ているのなら，その代謝を賦活することで眼圧 を下げることが可能となると考え, 私達は種久 の工夫を抗なうようになった。そのうちの成 功例が次に示すレーザーの応用 ${ }^{50,54)}$ である. 


\section{緑内障の治療-3 レーザー隅角形成術の問題点と炎の改良（図 10）}

レーザーを隅角組織に照射する方法が臨床で 使われるようになった。レーザーは図 10 の通 り,隅角組織に照射する。その斜線の部分を通つ て房水は排出されていくのであるが，隅角組織 を敢えて傷害したくない場合には線維柱帯の上 方または下方を照射してもよい. 多くの矛盾が あるので実際の機構とは異なるかもしれない が，その奏効機能はレーザーを照射することに より(図 10), 隅角組織が収縮し, 房水の流出す る領域が増加するためだと考えると解りやす い. 通常のレーザー隅角形成術 (LTP) は 700$1,000 \mathrm{mw}$ で 0.2 秒間照射する.

しかし我々の開発したレーザー隅角刺激術 laser trabeculostimulation (LTS) ${ }^{50)}$ は $50 \mathrm{mw}$ の超低出力で長時間 (1-2 秒) 刺激を行ない, い わば細胞をあぶるようにしている。これは眼の 灌流実験を通じ, 初期の緑内障では房水の通過 障害を改善し排出を促進出来る可能性があると 考えた結果である.幸い従来の LTP と比較し 我々のLTSもピロカルピン処理眼や無水晶体 眼に同等以上に機能することがわかった。
緑内障の内眼筋機能 : 散瞳および調節機能 (連続 近点, アコモドメーター)からの再評価 (表 2, 図 11)

次に高眼圧を示す緑内障眼においてヒト内眼 筋が障害されているかどうかについて考えた い.その研究はほとんどなされていない。とい うのは緑内障は通常, 両眼が障害されるので, 内 眼筋の機能（左右差）をみることが困難である 上に，個人差の方が大きいからである，そこで 緑内障の一つである片眼性の落屃症候群に注目 し, 緑内障の内眼筋機能 ${ }^{51)}$ を調べてみた。

内眼筋機能は個人差のコントロールをとるの が難しい.それで同一人物で同一の時期に僚眼 の健眼と比較できるよう, 我々は片眼性の落屃 症候群を観察した ${ }^{511}$. 内眼筋機能として, 瞳孔の 散瞳能力, 毛様体筋の収縮弛緩能をメルクマー ルとした。

患者さんの条件は，健眼の瞳孔縁と水晶体表 面に虹彩後癒着等の異常を認めないこと, ピロ カンビンを最初から点眼していないか，または 少なくとも 3 ケ月以上その点眼を中止している こと，アコモドメーター等の自覚的検査をする ため患者が協力的で意識の明瞭なこと, 眼圧の
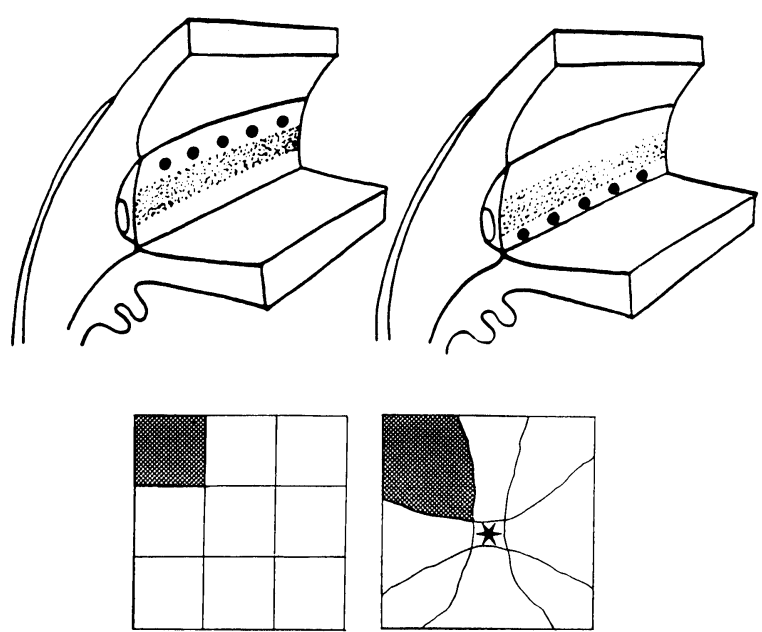

Fig. 10. Laser trabeculoplasty and the possible mechanism for the increase of outflow facility. When the laser was applied, the surrounding tissues contract, thereby the area for aqueous drainage would be wider, causing increase of the outflow facility. 
Table 2. Mydriatic effect of tropicamide $0.5 \%+$ phenylephrine hydrochloride $0.5 \%$.

\begin{tabular}{|cccc|}
\hline No & age $\mathbf{M} / \mathbf{F}$ & PSX & ipsilateral \\
\hline 1 & $45 \mathrm{M}$ & $7.0 \times 8.0$ & $9.0 \times 9.0(\mathrm{~mm})$ \\
\hline 2 & $59 \mathrm{M}$ & $6.0 \times 7.0$ & $7.0 \times 9.0$ \\
\hline 3 & $76 \mathrm{M}$ & $6.0 \times 7.0$ & $7.0 \times 7.5$ \\
\hline 4 & $68 \mathrm{~F}$ & $6.0 \times 6.5$ & $8.0 \times 9.0$ \\
\hline 5 & $63 \mathrm{~F}$ & $5.5 \times 5.5$ & $6.5 \times 6.5$ \\
\hline 6 & $69 \mathrm{M}$ & $5.5 \times 6.0$ & $7.0 \times 7.0$ \\
\hline 7 & $87 \mathrm{~F}$ & $6.0 \times 7.0$ & $8.0 \times 8.5$ \\
\hline 8 & $68 \mathrm{M}$ & $5.5 \times 6.0$ & $6.0 \times 6.5$ \\
\hline 9 & $76 \mathrm{~F}$ & $7.0 \times 8.0$ & $8.0 \times 8.0$ \\
\hline 10 & $74 \mathrm{M}$ & $7.0 \times 7.0$ & $8.5 \times 8.5$ \\
\hline 11 & $76 \mathrm{M}$ & $6.5 \times 7.0$ & $7.5 \times 7.5$ \\
\hline 12 & $81 \mathrm{~F}$ & $8.0 \times 8.0$ & $8.5 \times 8.5$ \\
\hline 13 & $76 \mathrm{~F}$ & $7.0 \times 8.0$ & $8.0 \times 8.0$ \\
\hline 14 & $82 \mathrm{~F}$ & $6.0 \times 7.0$ & $6.5 \times 6.5$ \\
\hline 15 & $61 \mathrm{M}$ & $6.0 \times 6.0$ & $8.0 \times 9.0$ \\
\hline 16 & $67 \mathrm{M}$ & $6.0 \times 6.5$ & $7.0 \times 8.0$ \\
\hline 17 & $58 \mathrm{M}$ & $6.0 \times 7.0$ & $\mathbf{1 9 0 . 8} \pm \mathbf{3 8 . 9}\left(\mathbf{m m}^{2}\right)$ \\
\hline mean & $\mathbf{6 9 . 8} \pm \mathbf{1 0 . 5}$ & $\mathbf{1 3 7 . 8} \pm \mathbf{3 0 . 0}$ & \\
\hline & & & 8650 \\
\hline
\end{tabular}

Differences between eyes with PSX and fellow eyes or an ageand sex- matched normal population were significant $(\mathrm{p}<0.01)$. PSX, pseudoexfoliation.

左右差が $5 \mathrm{mmHg}$ 以下であることである.

まず本症の両眼をミドリン(トロピカマイド) で散瞳した。ミドリン $\mathrm{P}^{\mathrm{R}}$ による最大散瞳の結 果（表 2) をみると，なんと 17 例全例で最大散 瞳径は健眼に対し抑制されていた。 7-8 mm と 充分に散瞳している例（症例 9，12，13）もある が, そのとき健眼の散瞳はより良好であった.ま た特に症例 9,12 では PE の沈着が強かったが, 両眼共によく散瞳し, 散瞳状態は瞳孔縁の PE 物質の沈着度と必ずしも一致しなかった。また 表 2 に示すように, 最大瞳孔面積は健眼に対し 患眼では有意に減少していた。もし後癒着や新 生血管のある例を意識して予め除外していな かったら，もっと強い散瞳抑制がみられたであ ろう。以上から緑内障があるとその側の虹彩の 平滑筋が障害されやすいことが示唆される。

毛様体筋の調節機能としてまず連続近点があ る. 連続近点は視標を近方で凝視させ, 次に遠
ざけて明瞭に見える点が試行回数と共に延長す るか否かを調べる，各々の振幅は異なっている が，患側と健側とでは差はなかった。

アコモドメーター（図 11）は石原式近点遠点 測定器に比へ, 視標の動きと記録が自動的に出 来, パターン化出来るので毛様体筋の機能をみ るために簡便である。そのうちわけは緊張時間 が健眼に比しやや延長しているもの, 緊張時間 が延長するか一定でないもの, 弛緩時間が主と して延長しているもの, また両眼ともに正常範 囲と考えられるものなど様々であった，再現性 のあった例をみると，アコモドグラムでは 4 型 のアコモドタイプが最も多く，まれに 2 型と 5 型を示した.つまり毛様体筋の反応は緑内障が あるかないかで左右差のあることがわかった.

以上のことから虹彩や毛様体の平滑筋の機能 が落屑症候群では影響を受けている可能性 ${ }^{51)}$ がある.したがって PE 物質の出現, 発症, 経過 

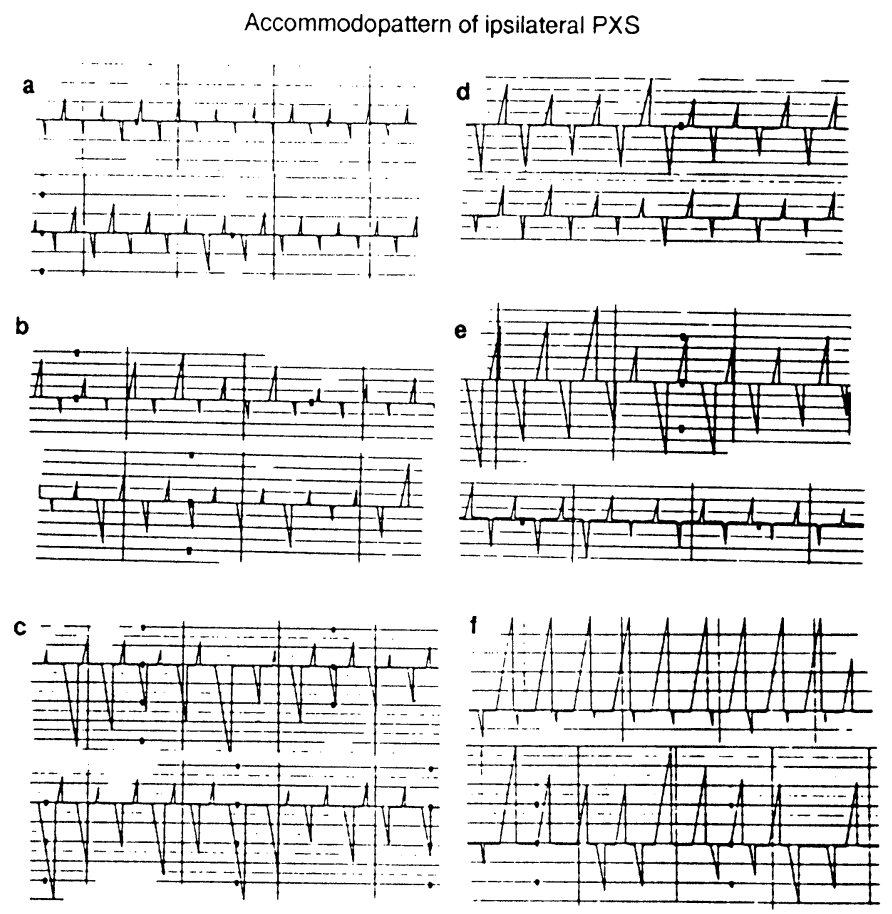

Fig. 11. Accommodogram of pseudoexfoliation (PXS). Upper line, PXS side; lower line, fellow eye. $(a-c)$ No differences were apparent, even when pseudoexfoliation material was evident by slit-lamp examination. (d, e) Pattern of contractile time was not constant in the affected eye; relaxation time was prolonged (e). Contractile time in the PXS eye was slower than in the normal fellow eye $(e, f)$. Originally presented by Suzuki ${ }^{50)}$.

などが内眼筋自体に影響を与えている。内眼筋 でないことが示唆される。

は単に光量の調節や遠近機能を司っているだけ

\section{緑内障の治療-4（図 12）}

緑内障の現在の非観血的治療は上記 1-3 であ る。緑内障には種久の病態がある。虚血が原因 で緑内障になることもあれば，高眼圧が原因と なって組織の虚血を誘導することもある。特に 血流の異常 ${ }^{63)}$, 眼内の炎症が原因で生じること もある. 脱臼白内障や膨化白内障のために高眼 圧緑内障になることもまれでない.網膜血管が 血流に何らかの異常が示唆されるいわゆる低眼 圧緑内障もある。緑内障眼では診断が下される 以前から, 網膜神経線維層が菲薄化したり欠 損 ${ }^{14)}$ することが知られている。緑内障は房水流 出率の低下によって生じるが, 房水流出率は流 出路の細胞や細胞外物質によってのみ規定され
るとは限らない。

家鬼眼でSP の眼内注射が異常な高眼圧を惹 起することが話題になっていた頃, Ueda ら ${ }^{59,60)}$ が虹彩および知覚神経末端からの SP 様物質の 放出を報告した．SPはヒトでは内眼筋の伝達 物質とはいえないが，特殊な条件下，たとえば ある種のブドウ膜炎では，ヒトでも，もしかす ると放出されているかもしれない. Atropine に 拮抗する頑固な縮瞳と眼圧異常（高眼圧, 低眼 圧）を経験するからである。動物眼では CGRP, BK, ATP 類, PGs, PAF などの存在 ${ }^{20,43)}$ または 生理的意義 ${ }^{11,22,30,54)}$ が眼でも報告されつつあ る。 


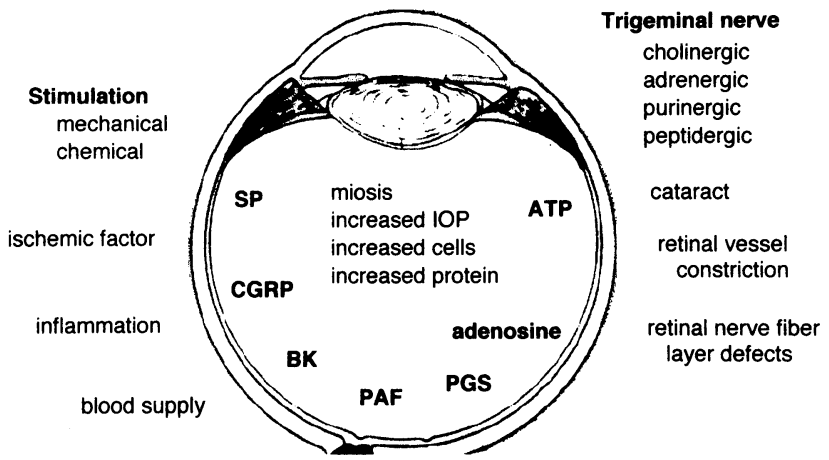

Fig. 12. Glaucoma and neuronal and humoral control of intraocular muscles.

房水流出率は種々の因子によって変化する. この房水流出率には内眼筋特に毛様体筋の収縮 と隅角内皮細胞の機能が重要である. 隅角組織 は神経分布はまれであるので, もし房水流出に 何らかの調節があるとすれば液性調節を強く受 ける可能性がある。その一方, 内眼筋は神経性 調節を強く受けているが, 液性調節機能も無視 できない.

したがって緑内障の治療は副交感ないし交感 神経作働薬のみでなく種々の生理活性物質によ る内眼筋の収縮弛緩, 隅角線維柱帯内皮細胞の

謝

内眼筋の基礎研究についてはほとんど触れていないが, Takayanagi, Watanabe らの優れた仕事がある。最後に
反応（レーザー治療, 薬物) を研究することに よって進歩する可能性がある. 化学伝達物質や オータコイドの観点から, 眼圧や神経眼科, 眼 薬理, 眼手術を考える時代がすぐそこに来てい るのかもしれない. 平滑筋の生理と薬理はとら え方によっては患者さんの病態と深くかかわっ ている分野で, 論理的な治療ができるはずであ る.しかしそのことがあまりにも当然すぎて,逆 に型にはまった旧態依然とした民間療法をして いる恐れがありはしないかと自戎している。

\section{辞}

あたり両教授のご指導に感謝します。

\section{文}

献

1) Acott, T.S., Kingsley, P.D., Samples, J.R. and van Buskirk, E.M. (1988). Human trabecular meshwork organ culture: morphology and glycosaminoglycan synthesis. Invest. Ophthalmol. Vis. Sci. 29: 90-100.

2) Barany, E.H. (1953). In vitro studies of the resistance to flow through the angle of the anterior chamber. Acta Soc. Med. Upsal. 59: 260-276.

3) Bill, A. (1970). Effects of norepinephrine, isoproterenol, and sympathetic stimulation on aqueous humor dynamics on vervet monkeys. Exp. Eye Res. 10: 31-46.

4) Bill, A. (1984). Physiology of the outflow mechanism. In: Applied pharmacology in the medical treatment of glaucomas, ed. by Drance, S.M. Grune \& Stratton Orlando. 111-143.

5) Brubaker, R.F. (1975). The effect of intraocular pressure on conventional outflow resistance in the enucleated human eye. Invest. Ophthalmol. $14: 286-292$.

6) Camras, C.B., Bito, L.Z. and Eakins, K.E. (1977). Reduction of intraocular pressure by 
prostaglandins applied topically to the eyes of conscious rabbits. Invest. Ophthalmol. Vis. Sci. 16: 1125-1134.

7) Chen, J. and Woodward, D.F. (1992). Prostanoid-induced relaxation of precontracted cat ciliary muscle is mediated by EP2 and DP receptors. Invest. Opthalmol. Vis. Sci. 33 : 31953201.

8) Coroneo, M.T., Korbmacher, C. and Flugel, C. (1991). Electrical and morphological evidence for heterogeneous populations of cultured bovine trabecular meshwork cells. Exp. Eye Res. $52: 375-388$.

9) Crawford, K.S. and Kaufman, P.L. (1991). Dose-related effects of prostaglandin F2 $\alpha$ isopropylester on intraocular pressure, refraction and pupil diameter in monkeys. Invest. Ophthalmol. Vis. Sci. 32 : 510-519.

10) Crean, E., Sherwood, M. and Casey, R. (1986). Establishment of calf trabecular meshwork cell cultures. Exp. Eye Res. 45: 503-512.

11) Drago, F. (1985). Effects of opiates on intraocular pressure of rabbits and humans. Clin. Exp. Pharmacol. Physiol. 12: 107-113.

12) Emi, K., Pederson, J.E. and Toris, C.B. (1989). Hydrostatic pressure of the suprachoroidal space. Invest. Ophthalmol. Vis. Sci. 30: 233-238.

13) Epstein, D.L., Hashimoto, J.M. and Anderson, P.J. (1981). Effect of iodoacetamide perfusion on the outflow facility of the eye. Invest. Ophthalmol. Vis. Sci. 20 : 625-631.

14) Epstein, D.L. (1994). Examination of the eye in glaucoma. In: Chandler and Grant's Glaucoma, ed. by Epstein, D.L., Lea \& Febiger, Philadelphia, pp. 14-101.

15) Erickson-Lamy, K.A. and Schroeder, A. (1990). Dissociation between the effect of aceclidine on outflow facility and accommodation. Exp. Eye Res. 50: 143.

16) Erickson-Lamy, K., Korbmacher, C., Schuman, J. and Nathanson, J. (1991). Effect of endothelin on outflow facility and accommodation in the monkey eye in vivo. Invest. Ophthalmol. Vis. Sci. 32: 492-495.

17) Erickson-Lamy, K.A. and Nathanson, J.A. (1996). Epinephrine increases facility of outflow and trabecular meshwork cAMP content in the human eye in vitro. Invest. Ophthalmol. Vis. Sci., In press.

18) Ethier, C.R., Coloma, F.M., de Kater, A.W. and Allingham, R.R. (1992). Retroperfusion studies of the aqueous outflow system. Part 1: Evaluation of technique using $\mathrm{N}$-ethyl maleimide. Invest. Ophthalmol. Vis. Sci. 34: 385-394.

19) Grant, W.M. (1951). Clinical measurements of aqueous outflow. Arch. Opthalmol. 46: 113131.

20) Hirai, R., Tamamaki, N., Hukami, K. and Nojyo, Y. (1994). Ultrastructural analysis of tyrosine hydroxylase, substauce $\mathrm{P}$, and calcitonin gene-related peptide immunoreactive nerve fibers in the rat iris. Ophthalmic Res. 26: 169-180.

21) Honkanen, R.R., Howard, E.F. and Abdel-Latif, A.A. (1989) Characterization of muscarinic receptors in the bovine iris sphincter using oligonucleotides specific for the M1-M2 subtypes. Invest. Ophthalmol. Vis. Sci. 30(Suppl) : 268.

22) Hosoki, R., Hisayama, T. and Takayanagi, I. (1987). Pharmacological evidence for the possible coexistence of multiple receptor sites for mammalian tachykinins in rabbit iris sphincter smooth muscle. Naunyn-Schmiedeberg Arch. Pharmacol. 335 : 290-295.

23) Kaufman, P.L. and Barany, E.H. (1976) Loss of acute pilocarpine effect on outflow facility following surgical disinsertion and retrodisplacement of the ciliary muscle from the scleral spur in the cynomologus monkey. Invest. Ophthalmol. Vis. Sci. 15 : 793.

24) Kawa, I.E., Higginbotham, E.J., Chang, I.L. and Yue, B.Y. (1993) Effects of antiglaucoma medications on bovine trabecular meshwork cells in vitro. Exp. Eye Res. 57: 557-565.

25) Konno, F. and Takayanagi, I. (1986). Comparison of the muscarinic cholinoceptors in the 
rabbit ciliary body and the guinea-pig ileum. Eur. J. Pharmacol. 132: 171-178.

26) Kubo, C., Suzuki, R., Yoshino, H. and Kurimoto, S. (1994). Theophylline and caffeine influence the ciliary muscle and the outflow facility of the eye. Excepta Medica, In: Current Aspects in Ophthalmology, vol 2, ed. by Shimizu, K., Elsevier Science Publishers BV, Amsterdam, pp. 1355-1360.

27) Lepplewienhues, A., Stakl, F. and Wiederholt, R. (1991). Differential smooth muscle-like contractile properties of trabecular meshwork and ciliary muscle. Exp. Eye Res. 53 : 33-38.

28) Lograno, M.D., Giovanazzi, D.S., Guarrera, A. and Nicosia, S. (1992). Effects of prostaglandins and PAF on the contractility of the bovine ciliary muscle. Pharmacol. Res. 25 : 195-202.

29) Lutjen-Drecoll, E. and Tamm, E. (1988). Morphological study of the anterior segment of cynomolgus monkey eyes following treatment with prostaglandin $\mathrm{F} 2 \alpha$. Exp. Eye Res. 47 : 761-769.

30) Masuda, Y., Yamahara, N.S., Tanaka M., Ryang, S. and Watanabe M. (1995). Characterization of muscarinic receptors mediating relaxation and contraction in the rat dilator muscle. Br. J. Pharmacol. 114: 769-776.

31) Mittag, T.W. (1996). Adrenergic and dopaminergic durgs in glaucoma. In: The glaucomas, ed. by Ritch, R., Shields, M. and Krupin, T., CV Mosby Co, St Louis. pp. 523-537.

32) Nathanson, J.A. and Mckee, M. (1995). Identification of an extensive system of nitric oxide producing cells in the cilliary muscle and outflow pathway of the human eye. Invest. Ophthalmol. Vis. Sci. $36: 1765-1773$.

33) Narita S. and Watanabe, M. (1982). Response of isolated rat iris dilator to adremergic and cholinergic agents and electrical stimulation. Life Sci. 30 : 1211-1216.

34) Nilsson, S.F.E., Samuelsson, M., Bill, A. and Stjernschantz, J. (1989). Increased uveoscleral outflow as a possible mechanism of ocular hypotension caused by prostaglandin F2 $\alpha-1$ isopropyl ester in the cynomolgus monkey. Exp. Eye Res. 48: 707-715.

35) Polansky, J.A., Wood, I.S., Maglio, M.T. and Alvarado, J.A. (1984). Trabecular meshwork cell culture in glaucoma research: evaluation of biological activity and structural properties of human trabecular cells in vitro. Ophthalmology. 91:580.

36) Potter, D.E. and Rowland, JM. (1978). Adrenergic drugs and intraocular pressure: Effects of selective $\beta$-adrenergic agonists. Exp. Eye Res. 27 : 615-625.

37) Reichert, R.W. and Shields, M.B. (1991) Intraocular pressure response to the replacement of pilocarpine or carbachol with echothiophate. Graefes. Arch. Clin. Exp. Opthalmol. 229 : 252.

38) Rosenberg, P., Higman, H. and Nachmansohn, D. (1960). An improved isolated single electroplax preparation. 1. Effect of compounds acting primarily at the synapses. Biochim. Biophys. Acta 44 : 151-160.

39) Ryang, S., Takei, S., Kawai, T., Imaizumi, Y. and Watanabe, M. (1990). Atropine-resistant relaxation induced by high $\mathrm{K}+$ in iris dilator of the rat and pig. Br. J. Pharmacol. $100: 401^{-}$ 406.

40) Shields MB : (1992). Textbook of glaucoma. 3rd ed. Williams \& Wilkins, Baltimore, Hong Kong, London. pp. 6.

41) Shiraishi, K. and Takayanagi, I. (1993) Subtype of muscarinic receptors mediating relaxation and contraction in the rat iris dilator smooth muscle. Gen. Pharmacol. 24 : 139-142.

42) Stone, R.A., Kuwayama, Y. and Laties, A.M. (1987). Regulatory peptides in the eye. Experientia 43 : 791-800.

43) Stone, R.A. (1994). Nervous system and intraocular pressure. In: The Glaucomas, ed. by Ritch, R, Schields, M.B. and Krupin, T. Mosby, St. Louis, Baltimore, chapter 17, pp. 357-383.

44) Suzuki, R. (1983). Neuronal influence on the mechanical activity of the ciliary muscle. $B r$. J. Pharmacol. 78 : 591-597.

45) Suzuki, R. and Kobayashi, S. (1983). Cholinergic inhibitory response in the iris dilator 
muscle. Invest. Ophthalmol. Vis. Sci. 24: 760-765.

46) Suzuki, R. and Kobayashi, S. (1983). Response of bovine intraocular muscles to transmural stimulation in the presence of various prostaglandins. Exp. Eye Res. 36 : 789-798.

47) Suzuki, R. and Kobayashi, S. (1984). Different effects of substance P and vasoactive intestinal peptide on the motor function of bovine intraocular muscles. Invest. Ophthalmol. vis. Sci. 24 : 1566-1572.

48) Suzuki, R., Yoshino, H. and Kobayashi, S. (1987). Different time courses of bovine iris sphincter and dilator muscles after stimulation. Ophthalm. Res. 19: 344-350.

49) Suzuki, R. and Kobayashi, S. (1989). Possible mechanisms related to contraction of the bovine iris sphincter in the presence of acetylcholine and carbachol. Doc. Ophthalmol. 70 : 293-300.

50) Suzuki, R., Yoshino H., Nakayama M. and Kurimoto, S. (1993). Comparison of laser trabeculostimulation with laser trabeculoplasty in open-angle glaucoma. Annals Ophthalmol. $24: 245-249$.

51) Suzuki, R. and Kurimoto S. (1992). Intraocular muscle function in pseudoexfoliation syndrome. Ophthalmol. 204 : 192-198.

52) Suzuki, R. and Anderson, P.J. (1994). A temperature dependent action of fluoride on aqueous outflow facility of the calf eye. Curr. Eye Res. 12: 1-7.

53) Suzuki, R., Karageuzian, T., Crean, E. and Anderson, P.J. (1996). Adrenergic influence on outflow facility and shape of cells of bovine trabecular meshwork tissue. Ophthalmol. 40: 4 .

54) Suzuki, R. (1996). Ocular cutflow facility with emphasis on neuronal regulation of intraocular smooth muscles. I Smooth Muscle Res.

55) Takayanagi, I., Saitoh, K., Koike, K. and Satoh, M. (1991). Characterization of muscarinic receptors in rabbit ciliary body smooth muscle using propylbenzilylcholine mustard. Gen. Pharmacol. 22 : 851-853.

56) Takayanagi, I., Shiraishi, K. and Satoh, M. (1992). Effects of ageing on responses of rabbit iris smooth muscles to agonists and field stimulation. Gen Pharmacol 23: 463-469.

57) Tamm, E.R., Fliigel, C., Stefani, F.H. and Lütjen-Drecoll, E. (1994). Nerve endings with structural characteristics of mechanoreceptors in the human scleral spur. Invest. Ophthalmol. Vis. Sci. 35 : 1157-1166.

58) Tripathi, B.J. and Tripathi, R.L. (1984). Effect of epinephrine in vitro on the morphology, phagocytosis and miotic activity of human trabecular endothelium. Exp. Eye Res. 33 : 731744.

59) Ueda, N., Muramatu, I., Hayashi, H. and Fujiwara, M. (1983). Effects of Met-enkepharin on the substance $\mathrm{P}$-ergic and cholinergic responses in the rabbit iris sphincter muscle. $J$. Pharmacol. Exp. Therap. $226: 507-511$.

60) Ueda, N., Muramatu, I., Hayashi, H., and Fujiwara, M. (1982). Trigeminal nerve: the possible origin of substance $\mathrm{P}$-nergic response in isolated rabbit iris sphincter muscle. Life Sci. 31 3: 369-375.

61) van Alphen, G.W.H.M., Wilhelm, P.B. and Elsenfeld, P.W. (1977). The effect of prostaglandins on the isolated internal muscles of the mammalian eye, including man. Doc. Ophthalmol. 42 : 397-415.

62) Wax, M.B., Molinoff, P.B. and Alvarado, J. (1989) Characterization of $\beta$-adrenergic receptors in culture human trabecular cells and in human trabecular meshwork. Invest. Ophthalmol. Vis. Sci. 30 : 51-57.

63) Williamson, T.H. and Harris, A. (1994). Ocular blood-flow measurement. Br. J. Ophthalmol. $78:$ : 939-945.

64) Yoshitomi, T., Ito, Y. and Inomata, H. (1985). Adrenergic excitatory and cholinergic inhibitory innervations in the human iris dilator. Exp. Eye Res. 40: 127-132. 
65) Yoshitomi, T. and Ito, Y. (1986). Presynaptic actions of noradrenaline on the dog ciliary muscle tissue. Exp. Eye Res. 43 : 181-185.

66) Yoshitomi, T. and Ito, Y. (1988). Effects of indomethacin and prostaglandins on the dog iris sphincter and dilator muscles. Invest. Ophthalmol. Vis. Sci. 29: 127-132.

67) Yoshitomi, T., Ishikawa, H., Haruno, I., Ishikawa, S. : Effect of histamin and substance P on the rabbit and human iris sphincter muscle. Graefe Arch. Clin. Exp. Ophthalmol. 233: 181185, 1995

68) Yousufzai, S.Y.K., Zheng, P. and Abdel-Latif, A.A. (1994). Muscarinic stimulation of arachidonic acid release and prostaglandin synthesis in bovine ciliary muscle: prostaglandins induce cyclic AMP formation and muscle relaxation. Exp. Eye Res. 58: 513-522. 